\title{
FAKTOR-FAKTOR YANG MEMPENGARUHI KINERJA KARYAWAN PT. MANDALA MULTI FINANCE Tbk CABANG MASAMBA
}

\author{
WARMAN, HAPID, SUHARDI M. ANWAR
}

\begin{abstract}
ABSTRAK
Pengertian kepuasan kerja, Lutnas (2000:126) merumuskan kepuasan kerja adalah suatu keadaan emosi seseorang yang positif maupun menyenangkan yang di hasilkan dan penilaian suatu pekerjaan atau pengalaman kerja.

Tujuan Penelitian berdasarkan rumusan masalah dan batasan masalah tersebut, maka penulis bertujuan untuk mengetahui pengaruh kepuasan kerja terhadap kinerja karyawan PT. Mandala Multi Finance Tbk Cabang Masamba.

Hasil penelitian PT. Mandala Multi Finance Tbk, yang berkantor pusat di Wisma Millenia Lt.6, Jl. Haryono Kav. 16, Jakarta Selatan 12810, didirikan pada tanggal 26 November 2000 dengan nama PT. Mandala Multi Finance Tbk. Dan mulai beroperasi pada bulan juni 2001.Sejak berdiri sampai dengan tahun 2012, PT. Mandala Multi Finance Tbk. Mempokuskan diri untuk memberikan kepuasan kepada para konsumen khususnya konsumen motor. Mulai awal tahun 2009, PT. Mandala Multi Finance Tbk. Cabang Masamba semakin melebarkan sayapnya dengan memberikan pinjaman berupa Pembiayaan Sepeda Motor dan Pembiayaan Syariah. Mulai tahun 2005, PT. Mandala Multi Finance Tbk lebih ekspansif dengan membuka cabang-nabang di sekitar Sulawesi Selatan serta pada tahun 2006 PT. Mandala Multi Finance Tbk mulai merambah pasar sumatera dengan membuka cabang di Bandar Lampung, pada tahun 2007 , PT. Mandala Multi Finance Tbk telah membuka 4 cabang baru yaitu di Kelapa Gading Jakarta, Medan, Palemabang, dan Cirebon. Pada tahun 2008, PT. Mandala Multi Finance Tbk juga telah membuka sejumlah cabang baru di pulau jawa, Sumatera, Kalimantan dan Sulawesi sehingga jumlah cabang sampai saat ini sekitar 120 cabang. Untuk pengembangan selanjutnya PT. Mandala Multi Finance Tbk di buka pada pertengahan 2008. Sejalan dengan tingkat kebutuhan masyarakat akan kebutuhan kendaraan yang semakin tinggi, pemasaran tidak hanya di wilayah Luwu Raya tetapi sudah merambah ke wilayah Sulawesi Tengah, Sulawesi Tenggara.

Kesimpulan Hasil analisis menunjukan secara simultan bahwa adanya pengruh yang signifikan faktor-faktor variabel independen (variabel bebas) yaitu Pendidikan (X1) 0,310 atau 31\% Keterampilan (X2) 0,088 atau 8,8\%, dan disiplin (X3) 0,752 atau 75,2\% mempunyai pengaruh yang signifikan terhadap variabel dependen /variabel terikat yaitu kinerja karyawan (Y) 0,956 atau 956\%.

Kata kunci : Faktor-faktor yang mempengaruhi kinerja karyawan PT. Mandala multi finance Tbk cabang masamba
\end{abstract}




\section{Pendahuluan}

\section{Latar Belakang}

Suatu perusahaan akan meningkat kinerjanya bila adanya kerjasama dan hubungan yang baik antara pimpinan dan karyawannya. Karena dengan meningkatkan kinerja karyawan otomatis akan meningkatkan kinerja perusahaan.

Persoalan karyawan yang terkadang di buat seperti buruh-buruh yang fasilitas dan pelayanan kurang di perhatikan oleh para pimpinannya, dan tidak ada hubungan dan kerja sama yang baik antara mereka. Persoalan ini tidak hanya terjadi di negaranegara yang sedang berkembang tetapi di negara maju pun persoalan tersebut juga ada. Salah satu penyebab ketidak puasan karyawan adalah sistem upah, hal ini sering tejadi di indonesia khususnya.

Ketidak puasan karyawan ini menimbulkan hal-hal yang tidak di inginkan dan dapat merugikan perusahaan yang bersangkutan. Misalnya : adanya aksi mogok kerja, kemungkinan karyawan meningkat, turunnya kinerja karyawan, dan lain-lain. Yang pada akhirnya akan menurunkan kinerja perusahaan itu sendiri. Maka, para pimpinan sebaiknya mengerti apa yang di butuhkan para karyawan dan mengetahui keinginan-kenginan apa yang membuat karyawan puas dan meningkatkan kinerjanya, berikut semua konsekwensinya, termasuk apa dan berapa bonus yang akan mereka terima jika target atau tujuan kerjanya tercapai. Sehingga para karyawan tidak melakukan hal-hal yang tidak sepantasnya di kerjakan.

Dan sedikit untuk mengetahui kepuasaan kerja yang merupakan hal yang bersifat individu dan mamiliki tingkat kepuasaan yang berbeda-beda, kepuasan kerja adalah sikap karyawan terhadap pekerjaan, situasi kerja, kerja sama di anatara pimpinan dan sesama karyawan.

Dan faktor-faktor yang mempengaruhi kepuasan kerja antara lain; faktor kepuasan financial, faktor kepuasan fisik, faktor kepusan sosial, dan faktor kepuasan fsikologi. Berdasarkan hal-hal yang telah diuraikan di atas, maka penulis berniat untuk mengadakan penelitian dengan judul "Faktor-faktor yang mempengaruhi kinerja karyawan PT.Mandala Multi Finance Tbk Cabang Masamba".

Masalah dalam penelitian adalah faktor-faktor apakah yang berpengaruh terhadap kinerja karyawan PT Mandala Multi Finance Tbk Cabang Masamba?. Tujuan dari penelitian yaitu untuk mengetahui pengaruh kepuasan kerja terhadap kinerja karyawan PT. Mandala Multi Finance Tbk Cabang Masamba.

\section{Metode Penelitian}

Tempat dan Waktu Penelitian

Adapun tempat penelitian dilakukan di PT. Mandala Multi Finance Tbk Cabang Masamba. Sementara waktu penelitian ini selama 2 bulan terhitung setelah pasca ujian profosal. 
Jenis dan Sumber Data

1. Data Primer

2. Data Sekunder

Populasi dan Sampel

Populasi pada pnelitian ini adalah semua karyawan PT. Mandala Multi Finance Tbk Cabang Masamba yang berjumlah 28 orang, dan sekaligus djadikan sebagai sampel.

\section{Metode Pengumpulan Data}

Metode pengumpulan data yang digunakan dalam penelitian ini adalah: (a) Penelitian lapangan (field research), yaitu penulis observasi PT. Mandala Multi Finance Tbk Cabang Masamba yang meliputi kegiatan observasi, (b)Penelitian kepustakaan (library research), yaitu cara pengumpulan data melalui bacaan berbagai ragam buku yang di anggap dapat menunjang permasalahan serta mempelajari berbagai pandangan-pandangan yang di kemukakan oleh para ahli yang di anggap relevan dengan mempelajari dokumen-dokumen yang ada serta penelitian yang di lakukan dengan membaca dan mempelajari buku-buku yang terkait dengan objek dn sasaran yang di teliti.

\section{Metode Analisis Data}

Setelah data-data yang penulis peroleh melalui pengumpulan data sebagaimana di terapkan di atas, maka tahap selanjutnya adalah dengan menganalisa data yang selanjutnya di proses atau di kerjakan sehingga dapat menampilkan kebenaran yang di pakai untuk menjawab persoalan yang telah di ajukan dalam penelitian dengan analisis regresi linier berganda dengan formulasi matematis sebagai berikut :

$$
\begin{aligned}
& \mathrm{Y}=\mathrm{a}+\mathrm{b} 1 \times 1+\mathrm{b} 2 \times 2+\mathrm{b} 3 \times 3+\ldots \ldots . \mathrm{e} \\
& \text { Dimana }: \mathrm{a}=\text { konstanta }
\end{aligned}
$$

$$
\begin{aligned}
& \mathrm{X} 1 \text { = Pendidikan } \\
& \mathrm{X} 2=\text { Keterampilan } \\
& \mathrm{X} 3=\text { Disiplin } \\
& \text { b1, b2, b3, = koefisien korelasi yang akan di cari } \\
& \mathrm{Y}=\text { Kinerja karyawan } \\
& \mathrm{e}=\text { standar error }
\end{aligned}
$$




\section{Hasil Penelitian Dan Pembahasan}

\section{Deskripsi Hasil Penelitian}

Gambaran Umum Penelitin

PT. Mandala Multi Finance Tbk, yang berkantor pusat di Wisma Millenia Lt.6, J1. Haryono Kav. 16, Jakarta Selatan 12810, didirikan pada tanggal 26 November 2000 dengan nama PT. Mandala Multi Finance Tbk. Dan mulai beroperasi pada bulan juni 2001.

Sejak berdiri sampai dengan tahun 2012, PT. Mandala Multi Finance Tbk. Mempokuskan diri untuk memberikan kepuasan kepada para konsumen khususnya konsumen motor. Mulai awal tahun 2009, PT. Mandala Multi Finance Tbk. Cabang Masamba semakin melebarkan sayapnya dengan memberikan pinjaman berupa Pembiayaan Sepeda Motor dan Pembiayaan Syariah.

Mulai tahun 2005, PT. Mandala Multi Finance Tbk lebih ekspansif dengan membuka cabang-nabang di sekitar Sulawesi Selatan serta pada tahun 2006 PT. Mandala Multi Finance Tbk mulai merambah pasar sumatera dengan membuka cabang di Bandar Lampung, pada tahun 2007 , PT. Mandala Multi Finance Tbk telah membuka 4 cabang baru yaitu di Kelapa Gading Jakarta, Medan, Palemabang, dan Cirebon. Pada tahun 2008, PT. Mandala Multi Finance Tbk juga telah membuka sejumlah cabang baru di pulau jawa, Sumatera, Kalimantan dan Sulawesi sehingga jumlah cabang sampai saat ini sekitar 120 cabang.

Untuk pengembangan selanjutnya PT. Mandala Multi Finance Tbk di buka pada pertengahan 2008. Sejalan dengan tingkat kebutuhan masyarakat akan kebutuhan kendaraan yang semakin tinggi, pemasaran tidak hanya di wilayah Luwu Raya tetapi sudah merambah ke wilayah Sulawesi Tengah, Sulawesi Tenggara.

Struktur Organisasi

Untuk lebih jelasnya struktur organisasi dari PT. Mandala Multi Finance Tbk Cabang Masamba dapat dilihat pada gambar di bawah ini ;

Gambar 2

Struktur Organisasi

PT. Mandala Multi Finance Tbk Cabang Masamba

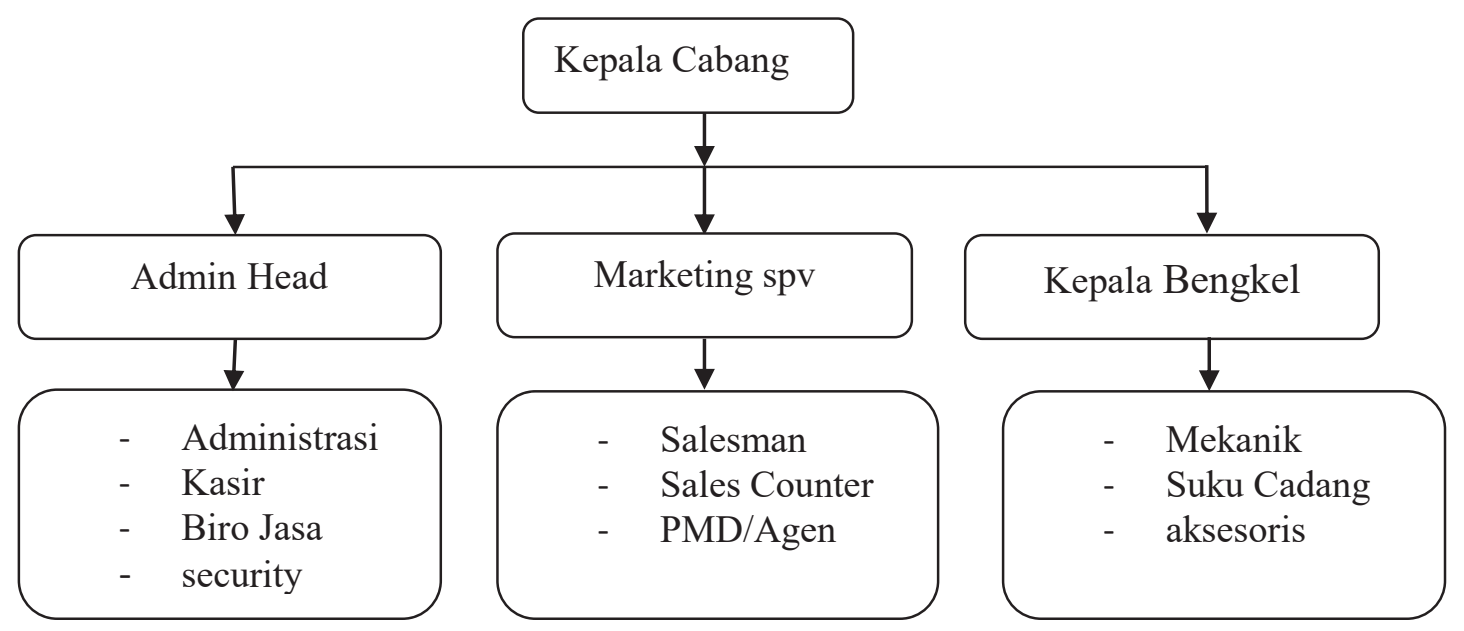


Tugas karyawan

Adapun tugas dan uraian tugas dari masing-masing karyawan PT. Mandala Multi Finance Tbk. Cabang Masamba dapat di uraikan sebagai berikut :

Kepala Cabang

a) Memimpin dan menentukan kebijaksanaan tata tertib perusahaan.

b) Mengurus dan menjaga perusahaan, menetapkan tata tertib serta cara menjalankan perusahaab dengan baik.

c) Mengusahakan hubungan yang baik dengan pemerintah serta pihak-pihak yang terkait dengan perusahaan serta masyarakat setempat

d) Mengusahakan rencana anggaran pendapatan dan belanja tahunan perusahaan.

e) Membuat kebijaksanaan perusahaan mengenai strategi pemasaran dan penjualan produk.

f) Menyusun program kerja tahunan cabang serta mengevaluasi kinerja bawahan.

Administrasion head

a) Bertnggung jawab atas segala izin yang menyangkut perusahaan.

b) Bertanggung jawab atas administrasi dan inventaris perusahaan serta menjalankan operasional perusahaan jika kepala cabang berhalangan hadir.

c) Membuat pembukuan serta laporan keuangan dengan tepat waktu

d) Membantu pimpinan dalam menentukan kebijaksanaan keuangan dan administrasi, termasuk menyiapkan rencana anggaran periodik

e) Mengatur jumlah stock kendaraan yang di order dari pabrik dan membuat laporan penjualan.

Marketing Supervisor

a) Mengatur dan menyusun rencana pemasaran

b) Memperbaiki dan meningkatkan hubungan kerja dengan para konsumen

c) Merencanakan, mengembangkan merumuskan, mengkoordinasikan, mengawasi kebijaksanaan program dan strategi di bidang pemasaran, promosi, penjualan dan penelitian pasar serta bertanggung jawab terhadap kelancaran penjualan perusahaan.

Kepala Bengkel

a) Bertanggung jawab atas pelayanan service motor konsumen pengguna motor.

b) Mengatur dan membuat program dalam rangka memuaskan pemilik sepeda motor

c) Menjaga stock spare part kendaraan di gudang

d) Meningkatkan kepuasan konsumen dalam menggunakan sepeda motor 
Tingkat pendidikan

Karyawan PT. Mandala Multi Finance Tbk Cabang Masamba ketika di lihat dari pembenaran pada saat penulis melakukan observasi dan wawancara, maka yang dapat kami simpulkan bahwa dokumen karyawan PT. Mandala Multi Finance Tbk Cabang Masamba di lihat dari tingkat pendididkannya yakni lulusan SMA/ Sederajat, D1, D2, S1, S2.

Pimpinan PT. Mandala Multi Finance Tbk Cabang Masamba saat di konfirmasi mengenai panjang pendidikan karyawannya membenarkan adanya hal tersebut, tuturnya melihat realitas yang terjadi pada perusahaan yang sementara ini kami jalankan maka yang terbersik dalam benak adalah bahwa akankah kekurangan di perusahaan yang di miliki oleh karyawan selamanya akan seperti itu. Sebenarnya kekurangan tersebut sangat kami rasakan saat ini terkadang terjadi kegalauan dalam memunculkan ide cemerlang untuk berusaha menutupi kekurangan perusahaan, oleh karenaya kami berupaya untk mendorong para karyawan tersebut untuk melanjutkan pendidikannya ke jenjang yang lebih tinggi lagi.si kepada para karyawa

Sejak kami memberikan dorongan dan motiva si kepada para karyawan untuk melanjutkan pendidikannya ke jenjang yang lebih tinggi maka ternyata takayal pada pare keryawanpun menyambut dengan riang menyambut sehinggan 2 tahun terakhir kami sanyat merasakan pola perubahan kerja di perusahaan semenjak mereka melakukan penndidikan walaupun masih banyak yang dalam penyelesaian stadi. Dengan terjadinya pola peningkatan tersebut maka kami juga tidak dapat di pungkiri bahwa pendidikan sangat penting untuk menunjang keberlangsungan dan keberhasilan suatu perusahaan untuk mendapatkan hasil yang memuaskan.

Jumlah karyawan

Analisis

Penentuan persamaan regresi linier berganda

Berdasarkan hasil perhitungan dengan bantuan program spss 18 sebagaimana barikut pada lampiran 5 di peroleh persamaan sebagai berikut:

Coefficients'

\begin{tabular}{|c|c|c|c|c|c|}
\hline \multirow[t]{2}{*}{ Model } & \multicolumn{2}{|c|}{$\begin{array}{c}\text { Unstandardized } \\
\text { Coefficients }\end{array}$} & \multirow{2}{*}{$\begin{array}{l}\text { Unstandardized } \\
\text { Coefficients } \\
\text { Beta }\end{array}$} & \multirow[t]{2}{*}{$\mathrm{t}$} & \multirow[t]{2}{*}{ sig } \\
\hline & B & Std.error & & & \\
\hline $1($ constanta $)$ & -1.859 & .657 & & -2.827 & .009 \\
\hline Pendidikan & .310 & .072 & .329 & 4.282 & .000 \\
\hline Keterampilan & .088 & .044 & .093 & 2.005 & .056 \\
\hline Disiplin & .752 & .083 & .665 & 9.041 & .000 \\
\hline
\end{tabular}

Sumber dari lampiran 4

Kinerja karyawan $=(-1.859)+0.310$ pendidikangaii +0.088 keterampilan +0.752 disiplin

Dimana masing- masing regresi tersebut mempunyai arti sebagai berikut:

bo $=(-1.859)$ 
konstanta sebasar -1.859 menyatakan bahwa jika variabel independen pendidikan, keterampilan dan disiplin dianggap konstan maka rata-rata kinerja karyawan sebesar $-1.859$

$\mathrm{b} 1=0.310$ pendidikan

koefisien regresi pendidikan sebesar 0,310 menyatakan bahwa setiap penambahan pendidikan sebesar satu satuan akan maningkatkan kinerja karyawan 0,310

b2 $=0.088$ keterampilan

koefisien regresi keterampilan 0,088 menyatakan bahwa setiap penambahan keterampilan sebesar satu satuan akan menaikkan kinerja karyawan 0,088

b3 $=0,752$ Displin

koefisien regresi disiplin 0,752 menyatakan bahwa setiap penambahan disiplin sebesar satu satuan akan menaikkan kinerja karyawan 0,752

\section{Koefisien Determinasi}

Analisis ini di gunakan untuk mengetahui besarnya proporsi sumbangan dengan variabel-variabel yang terdiri dari variabel indevenden/ variabel bebas yaitu pendidikan (X1), keterampilan (X2), dan Disiplin (X3) terhadap variabel devenden/ variabel terikat yaitu kinerja karyawan. Berdasarkan hasil perhitungan pada lampiran 5 di ketahui:

Tabel 5 : koefisien Determinasi / R Square

Model Summary

\begin{tabular}{|c|c|c|c|c|}
\hline Model & R & R Square & Adjusted R Square & $\begin{array}{c}\text { Std Error of the } \\
\text { Estimate }\end{array}$ \\
\hline 1 & $978^{\mathrm{a}}$ & 956 & 950 & 56179 \\
\hline
\end{tabular}

a Predictors : (constant), $\mathrm{X}$

sumber data : Lampiran 5

R Square $\left(\mathrm{R}^{2}\right)$ sebesar 0,596 artinya bahwa variasi perubahan variabel terikat yakni pendidikan (Y) Sebesar 95,6\% di sebabkan oleh variabel bebas yaitu Pendidikan (X1), keterampilan (X2), Dn variabel lain yang tidak teridentifikasi ke dalam model.

\section{Pengujian secara Simultan (uji F)}

Pengujian ini di maksud untuk mengetahui bagaimana variabel bebas yang terdiri pendidikan (X1), keterampilan (X2), dan disiplin (X3) berpengaruh terhadap variabel devenden (variabel terikat) yaitu kinerja karyawan (Y).

Adapun langkah-langkah pengujiannya adalah sebagai berikut :

1. Ho : $\mathrm{B}_{\mathrm{i}} \neq 0$, berarti ada pengaruh antara variabel pendidikan (X1), Keterampilan (X2), dan Disiplin (X3) berpengaruh terhadapa kinerja karyawan (Y)

2. Level Of sigmifikan pada tingkat $\alpha=5 \%$

3. Fhitung $<$ Ftabel berarti $\mathrm{H}_{\mathrm{o}}$ di terima $\mathrm{H}_{a}$ di tolak

Fhitung $>$ Ftabel berarti $\mathrm{H}_{a}$ di terima $\mathrm{H}_{\mathrm{o}}$ di tolak Tabel 6 : hasil Uji Secara Simultan (Uji F) 


\begin{tabular}{|c|r|r|l|l|l|}
\hline \multicolumn{1}{|c|}{ ANOVA $^{\mathbf{b}}$} \\
\hline Model & $\begin{array}{l}\text { Sum of } \\
\text { Squares }\end{array}$ & df & $\begin{array}{l}\text { Mean } \\
\text { Square }\end{array}$ & F & Sig. \\
\hline 1. Regression & 163.854 & 3 & 54.618 & 173.055 & $000^{\mathrm{a}}$ \\
Residual & 7.576 & 24 & 316 & & \\
total & 171.429 & 27 & & & \\
\hline
\end{tabular}

a. Predictors : (constant), DISPLIN, KETERAMPILAN, PENDIDIKAN

b. Dependent Variable : KINERJA KARYAWAN

Sumber Data : Lampiran 5

Dari hasil perhitungan diketahui bahwa : Fhitung $=173,055>$ Ftabel $=3,01$ atau tingkat signifikan sebesar 0,000 lebih kecil jika di bandingkan dengan tingkat $\alpha$ $=5 \%$ berarti bahwa variabel Pendidikan (X1), Keterampilan (X2), dan Disiplin (X3) berpengaruh terhadap kinerja karyawan (Y)

\section{Pengujian Secara Partial (Uji - t)}

Pengujian secara partial (uji $-\mathrm{t}$ ) di maksud untuk mengetahui tingkat signifikan antara variabel terikat secara statistik .

\section{Pembahasan}

Berdasarkan hasil uji $\mathrm{F}$ dalam analisis regresi linier berganda pada penelitian ini diketahui bahwa tingkat signifikan sebesar $0,000^{\mathrm{a}}$ lebih kecil jika di bandingkan dengan tingkat $\alpha=5 \%$ berarti bahwa variabel bebas yaitu pendidikan (X1), Keterampila (X2), dan Disiplin (X3) mempunyai pengaruh yang signifikan terhadap variabel devenden / variabel terikat yaitu kinerja (Y). Dengan demikian, hipotesis penelitian ini yang menduga bahwa faktor kepuasan yakni pendidikan, keterampila dan disiplin berpengaruh terhadapa peningkatan kinerja karyawan di PT. Mandala Multi Finance Tbk Cabang Masamba di terima atau terbukti kebenarannya.

Pendidikan (X1), Keterampila (X2), dan Disiplin (X3) mempunyai pengaruh yang signifikan terhadap variabel devenden / variabel terikat yaitu kinerja (Y) sebesar 0,956 atau 95,6 \%. Dengan demikian dapat disimpulkan bahwa perubahan kinerja karyawan (Y) dipengaruhi oleh faktor secara variabel bebas pada penelitian ini sebesar 0,044 atau $4,4 \%$.

Relatif tingginya pengaruh faktor pendidikan (X1), Keterampila (X2), dan Disiplin (X3) mempunyai pengaruh yang signifikan terhadap variabel devenden / variabel terikat yaitu kinerja (Y) menunjukkan bahwa asumsi pengabaian faktorfaktor diluar sisa hasil usaha misalnya faktor pelatihan, natinya di harapkan pada penelitian berikutnya perlu juga mengikutsertakan vaiabel peatihan.

Berdasarkan hasil regresi linier berganda untuk uji t diketahui bahwa tingkat signifikan variabel pendidikan $(\mathrm{X} 1=0,000)$, Keterampilan $(\mathrm{X} 2=0,056)$, dan Displin $(\mathrm{X} 3=0,000)$. Dengan demikian hipotesis pada penilitian ini yang menduga bahwa faktor kepuasan yakni pendidikan, keterampilan dan disiplin berpengaruh terhadap 
peningkatan kinerja karyawan PT. Mandala Multi Finance Tbk Cabang Masamba di terima atau terbuukti kebenarannya.

Faktor Pendidikan (Xwan pada b1) mempunyai pengaruh positif signifikn terhadap peningkatan kinerja karyawan PT. Mandala Multi Finance Tbk Cabang Masamba memeberikan opini/persepsi yang positif terhadap faktor pendidikan di antaranya perbedaan $\mathrm{n}$ kary jenjang pendidikan karyawan dapat mempengaruhi pola kinerja, penetapan karyawan pada bidang pekerjaan yang sesuai dengan disiplin ilmunya masing-masing, dan jenjang pendidikan mempengaruhi besarnya tingkat pendapatan karyawan. Faktor keterampilan (X2) mempunyai pengaruh positif signifikan sebesar $=0,088$ atau 8,8\% artinya karyawan PT. Mandala Multi Finance Tbk Cabang Masamba akan memberikan opini/ peresepsi yang positif terhadap faktor keterampilan diantaranya keterampilan harus dimiliki oleh masing-masing karywan. Tinggkat keterampilan itu penting, dan setiap karyawan memiliki keterampilan yang berbeda dalam mendukung kinerja masing.masing.

Sedangkan faktor disiplin (X3) mempunyai pengaruh positif signifikan sebesar $=0,752$ atau 7,5\% artinya karyawan di PT. Mandala Multi Finance Tbk Cabang Masamba akan memberikan opini/ peresepsi yang positif terhadap faktor disiplin di antarany kegiatan perusahaan dilakukan sesuai dengan jadwal yang di rencanakan, penyelesaian tugas hendaknya tepat waktu, dan sebagian besar waktu karyawan digunakan untuk bekerja.

Berdasarkan besarnya pengaruh faktor pendidikan (X1), Keterampilan (X2), dan Disiplin (X3) tersebut terhadap kinerja karyawan (Y), maka dapat disimpulkan bahwa variabel Disiplin (X3) mempunyai pengaruh dominian terhadap kinerja karyawan (Y)

\section{Penutup}

Kesimpulan dari penelitian ini adalah: (a) Hasil analisis menunjukan secara simultan bahwa adanya pengruh yang signifikan faktor-faktor variabel independen (variabel bebas) yaitu Pendidikan (X1) 0,310 atau 31\% Keterampilan (X2) 0,088 atau $8,8 \%$, dan disiplin (X3) 0,752 atau $75,2 \%$ mempunyai pengaruh yang signifikan terhadap variabel dependen /variabel terikat yaitu kinerja karyawan (Y) 0,956 atau 956\%, (b) Variabel Disiplin (X3) 0,752\% atau 75,2\% mempunyai pengaruh paling dominan terhadap kesetiaan konsumen terhadap kinerja karyawan (Y) 0,956 atau 95,6\%, (c) Secara simultan pengaruh pendidikan (X1), Keterampilan (X2), dan Disiplin (X3) terhadap kinerja Karyawan (Y) di tunjukan oleh nilai R Square sebesar 0,956 atau 95,6\%. Dengan demikian dapat disimpulkan pula bahwa perubahan kinerja karyawan $(\mathrm{Y})$ di pengaruhi oleh faktor lain secara variabel bebas pada penelitian ini sebesar 0,044 atau 4,4\%, (d) Berdasarkan hasil regresi linier berganda untuk uji t di ketahui bahwa tingkat signifikan variabel Pendidikan $(\mathrm{X} 1=$ 0,000), Keterampilan $(X 2=0,056)$, dan Disiplin $(X 3=0,000)$. Dengan demikian 
hipotesis pada karyawan PT. Mandala Multi Finance Tbk Cabang Masamba di terima atau terbukti kebenarannya.

Adapun saran dari penelitian ini adalah: (a) Bagi Pimpinan PT. Mandala Multi Finance Tbk Cabang Masamba. Adapun variabel-variabel yang mempengaruhi kinerja karyawan (Y) yaitu variabel Pendidikan (X1), Keterampilan (X2), dan Disiplin (X3) sudah memiliki efektifitas yang maksimal. Adapun aspek-aspek yang berpengaruh positif dan signifikan tehadapa kinerja karyawan (Y) hendaknya di perahankan dan di butuhkan kekreatifan dan keinovatifan unutuk terus dapat meningkatkan aspek-aspek tersebut, (b) Bagi Peneliti lain; Peneliti dapat memasukan faktor-faktor lain misalnya penelitian, nantinya di harapkan pada penelitian berikutnya yang meneliti tentang topik yang mirip dengan penelitian ini dapat memberikan tambahan variabel yang mampu mengukur Kinerja Karyawan (Y) dan Peneliti dapat menggunakan sarana objek penelitian lain dalam hal PT. Mandala Multi Finance Tbk Cabang Masamba, agar dapay memberikan informasi yang nantinya dapat dijadikan sebagai pembanding dalam menentukan seberapa besar pengaruh Pendidikan (X1), Keterampilan (X2), dan Disiplin (X3) berperan penting dalam meningkatkan Kinerja Karyawan (Y)

\section{Daftar Pustaka}

Adam. 2001. Kumpulan Materi Kuliah Evaluasi Kinerja. PPS. Univ Muslim Indonesia Makassar

Ambar Teguh Sulistiyani. 2003. Manajemen Sumber Daya Manusia. Jakarta . Badan Penerbit IPWI.

Anonim. 2011. Buku Pedoman Skripsi, STIE Muhammadiyah, Palopo.

Arikunto, J. 2003. Manajemen Penelitian. PT, Rineka Cipta, Jakarta

Anwar . 2000, Perilaku Keorganisasian. Edisi Pertama. Penerbit Ghalia Indonesia. Anggota IKAPI.

As'ad, 2000. Psikologi Industri, Edisi keempat, liberti. Yogyakarta.

Alex. S, 2002. Pentingnya Pengaruh Kinerja. Puslit . petra. Ac.id

Barry, 2002. Ratail Manajemen : A Strategic Approach, pustaka Hidayah Cm/catalog 1/index.php.

Bayu. 2001. Manajemen Sumber Daya Manusia, salemba Empat jakarta 
Bernard. 2009. Perilaku Organisasi dan Psikoklogi Personalia. Edisi Kedua, penerbit. PT. Rineka Cipta. Jakarta.

Burt. 2005. Perilaku Organisasi. Edisi Petama.Penerbit. Sinar Baru Bandung.

Cahyono. 2001. Manajemen Strategi. Jakarta. Badan Penerbit IPWI

Dajan. 2000. Pengantar Penelitian Ilmiah. Penerbit. Tarsito. Bandung .

Hadi poerwono. 2002. Pengantar Metode Statistik. Penerbit . LP3ES. Jilid Satu dan Dua. Jakarta

Hamidah. 2002. Teori Perilaku Konsumen. Dijilid. Petra.ac.id. di akses 18 februari 2011.

Hasibuan. 2001. Organisasi Dan Motivasi Dasar Peningkatan Produktivitas. Penerbit. Bumi Aksara. Bandung

Hamire. 2000. Manajemen Sumber Daya Manusia. Penerbit . mandar maju. Bandung

Handoko. 2000. Kepuasan Kerja http://id.wikipedia.org/wiki di akses 26 januari 2012.

Kans. 2000. Manajemen Sumber Daya Manusia. Penerbit Bumi Aksara Jakarta.

Locke. 2001. Manajemen Tenaga Kerja Indonesia. Edisi ketujuh. Penerbit . Bumi Aksara. Bandung.

Luthans . 2000. The Islamic development Economis, kuala Lumpur, Malaysia.

Notoadmojo . 2008. Produktifitas Kinerja. Penerbit Toha Putri, Malang.

Mangkunegara. 2001. Manajemen Sumber Daya Manusia Perusahaan. Gramedia Pustaka Tama, Jakarta.

Moenir . 2004. Pengembangan Sumber Daya Manusia Terhadap Kemajuan Kerja. Edisi Kedelepan. Bumi Aksara. Bandung.

Munandar, 2001. Psikiologi Industri, Edisi Keempat, Liberti, Yogyakarta

Prawirosentomo. 2000. Manajemen Sumber Daya Manusia, BPFE Yogyakarta. 
Rasnupandoyo. 2003. Tekhnik Manajemen Latihan dan Pembinaan. Penerbit Angkasa. Bandung.

Raviyanto. 2005. Manajemen Prestasi Kerja. Penerbit. Rajawali. Jakarta.

Robbins. 2001, perilaku Orgamisasi, jilid 11, Edisi 9, Raja Grafindo pustaka, jakarta.

Strauss dan Sayles, 2001. Manajemen Kinerja, Edisi Pertama. Penerbit Graha ilmu. Yogyakarta.

Supriadi. 2008. Manajemen Sumber Daya Manusia. Penerbit . Andi Offset. Yogyakarta .

Thoha. 2003. Kinerja. cetakan Pertama. Penerbit. Badan Penerbit FKM UI. Depok.

Utami. 2004. Pengukuran Kinerja. penerbit. Gramedia Pustaka Utama. Jakarta.

Vaizal. 2004. Sistem Informasi Untuk Pengambilan Keputusan. Cetakan Kesembilan. Penerbit. Rajawali. Jakarta.

Wijayanti. 2001. Pengembangan Sumber Daya Manusia Dalam Rangka Pembangunan Nasional. Penerbit. Rajawali. Jakarta

..........., 2006. Prosedur Penelitian Suatu Pendekatan Praktek PT.Rineka Cipta, Jakarta

............, 2001. Faktor-faktor yang mendorong kepuasan. http://jurnalsdm.blogspot.com. 